\title{
Editorial
}

\section{Leaching/Bioleaching and Recovery of Metals}

\author{
Laura Castro ${ }^{1,2, * \mathbb{D}}$, María Luisa Blázquez ${ }^{2}$ and Jesús Ángel Muñoz ${ }^{2}$
}

1 Department of Applied Mathematics, Materials Science and Engineering and Electronic Technology, School of Experimental Sciences and Technology, Rey Juan Carlos University, 28933 Móstoles, Spain

2 Department of Chemical and Materials Engineering, University Complutense of Madrid, 28040 Madrid, Spain; mlblazquez@quim.ucm.es (M.L.B.); jamunoz@quim.ucm.es (J.Á.M.)

* Correspondence: laura.castro@urjc.es

Citation: Castro, L.; Blázquez, M.L.; Muñoz, J.Á. Leaching/Bioleaching and Recovery of Metals. Metals 2021, 11, 1732. https://doi.org/10.3390/ met11111732

Received: 14 October 2021

Accepted: 28 October 2021

Published: 29 October 2021

Publisher's Note: MDPI stays neutral with regard to jurisdictional claims in published maps and institutional affiliations.

Copyright: (c) 2021 by the authors. Licensee MDPI, Basel, Switzerland. This article is an open access article distributed under the terms and conditions of the Creative Commons Attribution (CC BY) license (https:/ / creativecommons.org/licenses/by/ $4.0 /)$.

\section{Introduction and Scope}

Hydrometallurgical processes for metal extraction are becoming more and more popular as average ore grades are declining and huge tonnages of tailings and recycle materials containing valuable metals are being accumulated all around the world. Hydrometallurgy and, more recently, bio-hydrometallurgy have brought some added value to these processes since they can recover large amounts of metals using aqueous solutions and chemical reagents that could be provided by certain microorganisms. In addition, environmental risks associated with the accumulation of hazardous residues from metallurgical industries could be overcome by applying bio-hydrometallurgical methods. Hydrometallurgy of base metals, particularly $\mathrm{Cu}, \mathrm{Zn}, \mathrm{Ni}$, etc., is a well-documented process, but other metals, particularly strategic ones (cobalt, lithium, rare earths, etc.), have not yet deserved so much attention from the scientific community. In the same way, the field of bio-hydrometallurgy has focused mainly on a few metals, so there is still room for improvement.

\section{Contribution to the Special Issue}

Researchers around the globe investigating the advances in the chemical and biological dissolution of metals from diverse raw materials and the recovery of metals from aqueous solutions using different biochemical processes have been invited to submit research papers so that readers can recognize the common points between them. Among the submitted manuscripts, nine papers have been published in the issue.

\subsection{Chemical Leaching}

Different chemical treatments and leaching alternatives have been proposed to improve the dissolution of valuable metals. Articles that deal with chemical leaching have been considered for this Special Issue.

Quezada et al. [1] proposed the pretreatment of a mineral sample from a copper mining company $(0.79 \% \mathrm{Cu}, 1.99 \%$ chalcopyrite) in chloride media to improve the dissolution of copper from sulfide ores. Pretreatment products, such as $\mathrm{CuSO}_{4}, \mathrm{NaFe}_{3}\left(\mathrm{SO}_{4}\right)_{2}(\mathrm{OH})_{6}$, and $\mathrm{S}^{0}$, were identified, and a copper extraction of $93.1 \%$ was obtained at $90{ }^{\circ} \mathrm{C}$ with $50 \mathrm{~g} / \mathrm{L}$ of $\mathrm{Cl}^{-}$and $0.2 \mathrm{M}$ of $\mathrm{H}_{2} \mathrm{SO}_{4}$ after curing under optimum conditions $\left(15 \mathrm{~kg} / \mathrm{t}\right.$ of $\mathrm{H}_{2} \mathrm{SO}_{4}$, $25 \mathrm{~kg} / \mathrm{t}$ of NaCl , and 15 days). Aracena et al. [2] reported the treatment of a converter $(36 \mathrm{wt} \% \mathrm{Cu})$ using ammonium hydroxide at room temperature for copper recovery. The hydronium ion from ammonium hydroxide dissociation was the main oxidant of most of the copper compounds in slag $\left(\mathrm{CuO}, \mathrm{Cu}_{2} \mathrm{O}\right.$, and $\left.\mathrm{Cu}\right)$. The particles contain a large amount of microcracks (porosity) in their refractory structure. The increase in temperature and $\mathrm{NH}_{4} \mathrm{OH}$ concentration leads to a decrease in particle size and higher copper recoveries, $84.8 \%$. Leaching kinetics of the leaching solution through the porosity were explained by the intraparticle diffusion model (the reaction order was 1.2, and the activation energy was $42.3 \mathrm{~kJ} / \mathrm{mol}$ between 283 and $333 \mathrm{~K}$ ). 
Karimov et al. [3] studied the precipitation arsenic sulfide from the nitric acid leachate of refractory sulfide concentrates of nonferrous metals containing iron (III) ions using sodium hydrosulfide (NaHS/As $=2.4-2.6$ ). The highest degree of precipitation of arsenic (III) sulfide (95-99\%) without seed occurs at a $\mathrm{pH}$ range of 1.8 to 2.0 and a NaHS/As molar ratio of 2.8. The introduction of seed crystal remarkably improves the precipitation of arsenic (III) sulfide. An increase in seed crystal consumption from 0 to $34 \mathrm{~g} / \mathrm{L}$ in the solution promoted the arsenic precipitation from $36.2 \%$ to $98.1 \%$ at $\mathrm{pH}=1$.

\subsection{Bioleaching}

Bio-hydrometallurgy uses microorganisms to extract metals from primary ores and secondary resources such as concentrates and waste materials in aqueous solutions. Biotechnological advances in extractive metallurgy have been included in this Special Issue.

Khachatryan et al. [4] studied the potential of the newly isolated strain Leptospirillum ferriphilum CC for bioleaching of pyrite and chalcopyrite in pure or mixed culture with other iron- and/or sulfur-oxidizing bacteria. Microbial $\mathrm{Fe}^{2+}$ oxidation was competitively inhibited by $\mathrm{Fe}^{3+}$, and the presence of heavy metal ions influenced the oxidation of $\mathrm{Fe}^{2+}$ by L. ferriphilum CC (toxicity: $\mathrm{Co}>\mathrm{Zn}>\mathrm{Ni}>\mathrm{Cu}$ ). The comparison of iron oxidation kinetic parameters of L. ferriphilum CC with other strains indicated the high potential of the strain L. ferriphilum CC in bioleaching processes of ores and concentrates.

The transition from fossil fuels to renewable energy and the development of new technologies have increased the mining of strategic metals and nonconventional minerals. Castro et al. [5] investigated the dissolution of heavy metals from phosphate minerals (aluminum phosphate, turquoise, and monazite) using the fungus Aspergillus niger. A. niger was able to reach $8.81 \mathrm{mg} / \mathrm{L}$ of copper and up to $1.37 \mathrm{mg} / \mathrm{L}$ of REE in the aqueous phase. In addition, $A$. niger is involved in the precipitation of secondary minerals $(\mathrm{Cu}$ and REE oxalates).

Postconsumer wastes are another source of valuable and critical metals that can be treated using bio-hydrometallurgy for value recovery. Abhilash et al. [6] studied the extraction of copper and other metals $(\mathrm{Cu}, \mathrm{Ni}, \mathrm{Co}, \mathrm{Fe}$, and $\mathrm{Al})$ from a shredded printed circuit board using bacterial strains of Acidithiobacillus ferrooxidans and Acidithiobacillus thiooxidans and a fungal strain, $A$. niger. Bioleaching using a mixed culture of $A$. ferrooxidans and $A$. thiooxidans recovered $93 \% \mathrm{Cu}$ at $308 \mathrm{~K}, \mathrm{pH} 2$, using $8 \%$ pulp density in 10 days, whereas bioleaching using $A$. niger reached a yield of $66 \% \mathrm{Cu}$ under similar experimental conditions. Copper from the leachate obtained under optimized conditions was separated and purified (>99\% pure copper sulfate) using Acorga M5640 by solvent extraction.

\subsection{Adsorption}

Adsorption is one of the major strategies of metal recovery, and research works on REE uptake have been considered for this Special Issue. He et al. [7] developed a new phosphorylated hydrogel (algal biomass/PEI) for the recovery of $\operatorname{Pr}(\mathrm{III})$ and $\operatorname{Tm}(\mathrm{III})$ from acidic leachates. The optimum $\mathrm{pH}$ was close to 5, isotherms fitted to the Langmuir equation $\left(q_{\max }=2.14 \mathrm{mmol} \mathrm{Pr} \cdot \mathrm{g}^{-1}\right.$ and $\left.1.57 \mathrm{mmol} \mathrm{Tm} \cdot \mathrm{g}^{-1}\right)$, and fast sorption kinetics was represented by the pseudo-second-order rate equation. Furthermore, the functionalized hydrogel can be used for sorption and desorption cycles, and finally, a pure REE precipitate can be obtained by selective precipitation using oxalic acid. Breuker et al. [8] reported the selective biosorption of REE by different microorganisms from acid solutions. The Gram-positive bacterium Bacillus subtilis adsorbed with greater selectivity ytterbium and lutetium than the Gram-negative bacteria Leisingera methylohalidivorans and Phaeobacter inhibens. On the other hand, fungi (Catenulostroma chromoblastomyces, Pichia sp.) bound preferably middle rare earth elements.

In addition, adsorption is used to recover potentially toxic elements from water impacted by mining activities (acid mine drainages). Castro et al. studied the capability of iron precipitates generated by an anaerobic microbial consortium to remove arsenite $\left(K_{\mathrm{F}}=0.476 \mathrm{~L} / \mathrm{g}, n=2.13\right)$ and arsenate $\left(q_{\max }=0.64 \mathrm{mmol} / \mathrm{g}, K_{\mathrm{L}}=0.019 \mathrm{mmol} / \mathrm{L}\right)$ from 
aqueous solution. Furthermore, water samples from Caracarani River (Chile) polluted with arsenic and zinc were treated with the iron precipitates encapsulated in alginate beads in continuous systems [9].

\section{Conclusions}

The Special Issue "Leaching/Bioleaching and Recovery of Metals" addresses research articles covering the chemical and biological dissolution of metals from diverse raw materials and the recovery of metals from aqueous solutions using different biochemical processes, including studies reporting the novelty results of such aspects, particularly those relative to strategic metals, from both a fundamental scientific and an industrial point of view. The guest editors believe that this collection of papers may be useful to researchers who are actively involved (directly or indirectly) in this field. This Special Issue was successful already, and we hope that these articles can encourage more research works, debates, and discussions in the field.

Funding: This research received no external funding.

Acknowledgments: The guest editors thank all who have aided in the successful development of this Special Issue. The guest editors would like to thank all the authors who submitted their manuscripts and were willing to share their research works in this Special issue. We would especially like to mention the reviewers who agreed to review the articles and provide suggestions to improve the quality of the manuscripts. Finally, I would like to acknowledge the contribution and support of the editors and the Section Managing Editor, Kinsee Guo, and also all the members of the Metals Editorial Office.

Conflicts of Interest: The authors declare no conflict of interest.

\section{References}

1. Quezada, V.; Roca, A.; Benavente, O.; Cruells, M.; Melo, E.; Hernández, M. Pretreatment to Leaching for a Primary Copper Sulphide Ore in Chloride Media. Metals 2021, 11, 1260. [CrossRef]

2. Aracena, A.; Valencia, A.; Jerez, O. Ammoniacal System Mechanisms for Leaching Copper from Converter Slag. Metals 2020, 10, 712. [CrossRef]

3. Karimov, K.; Rogozhnikov, D.; Kuzas, E.; Dizer, O.; Golovkin, D.; Tretiak, M. Deposition of Arsenic from Nitric Acid Leaching Solutions of Gold-Arsenic Sulphide Concentrates. Metals 2021, 11, 889. [CrossRef]

4. Khachatryan, A.; Vardanyan, N.; Vardanyan, A.; Zhang, R.; Castro, L. The Effect of Metal Ions on the Growth and Ferrous Iron Oxidation by Leptospirillum ferriphilum CC Isolated from Armenia Mine Sites. Metals 2021, 11, 425. [CrossRef]

5. Castro, L.; Blázquez, M.L.; González, F.; Muñoz, J.A. Bioleaching of Phosphate Minerals Using Aspergillus niger: Recovery of Copper and Rare Earth Elements. Metals 2020, 10, 978. [CrossRef]

6. Abhilash; Tabassum, S.; Ghosh, A.; Meshram, P.; van Hullebusch, E.D. Microbial Processing of Waste Shredded PCBs for Copper Extraction Cum Separation-Comparing the Efficacy of Bacterial and Fungal Leaching Kinetics and Yields. Metals 2021, 11, 317. [CrossRef]

7. He, C.; Salih, K.A.M.; Wei, Y.; Mira, H.; Abdel-Rahman, A.A.-H.; Elwakeel, K.Z.; Hamza, M.F.; Guibal, E. Efficient Recovery of Rare Earth Elements (Pr(III) and Tm(III)) From Mining Residues Using a New Phosphorylated Hydrogel (Algal Biomass/PEI). Metals 2021, 11, 294. [CrossRef]

8. Breuker, A.; Ritter, S.F.; Schippers, A. Biosorption of Rare Earth Elements by Different Microorganisms in Acidic Solutions. Metals 2020, 10, 954. [CrossRef]

9. Castro, L.; Ayala, L.A.; Vardanyan, A.; Zhang, R.; Muñoz, J.Á. Arsenate and Arsenite Sorption Using Biogenic Iron Compounds: Treatment of Real Polluted Waters in Batch and Continuous Systems. Metals 2021, 11, 1608. [CrossRef] 